\title{
The Existence Of Benang Stokel Waterfall Tourism To Community Income
}

\section{Ecces: \\ Economics Social and Development Studies}

\author{
Desi Suryati ${ }^{1}$ \\ Baiq Salkiah ${ }^{2}$ \\ Universitas Nahdlatul Wathan Mataram ${ }^{1,2}$ \\ Jln Kaktus 1-3 Gomong Mataram, NTB, Indonesia \\ Email : desisuryatiunw@gmail.com , baiq salkiah@yahoo.com \\ (Article history) Received: 2020-11-02, Revised: 2020-12-16, Accepted: 2020-12-17, \\ Available online: 2020-12-17, DOI: https://doi.org/10.24252/ecc.v7i2.16286 \\ http://journal.uin-alauddin.ac.id/index.php/ecc/index
}

\section{Abstract: The Existence of Benang Stokel Waterfall Tourism to Community Income}

The tourism sector is a sector that has the potential to be developed, especially in West Nusa Tenggara. So the program of developing and utilizing the resources and potential of regional tourism is expected to contribute to economic development, especially for the income of the surrounding community. Central Lombok is one of the districts that have the potential to develop its tourism sector. One of the famous tourist destinations in Central Lombok district is the Benang Stokel Waterfall Tour. The existence of this tour provides a multiplier effect, especially on the income of the people around the tourist attractions. The purpose of this study was to determine the influence of the existence of Benang Stokel Waterfall Tour on people's income. This type of descriptive research using a quantitative approach, the number of samples of 30 people based on the determination of the sample by purposive sampling. The data source is the primary data equipped with secondary data. The data collection method used a questionnaire, namely a closed questionnaire, observation, and documentation, data analysis using statistical tests and statistical analysis. The results of statistical tests for the $t$ value of 2.217 is greater than the t table value of 2.045 at a significant level of $5 \%$ or $2.217>2.045$. This shows that Benang Stokel Waterfall Tourism has an effect on people's income in Central Lombok. The existence of Benang Stokel Waterfall Tourism provides business opportunities for the community. Job opportunities that exist in the vicinity of tourist spots such as motorcycle taxi drivers, traders, and parking attendants with a mindseat that are formed are mindset guides, meaning that every ojek driver, trader, and parking attendant job has the ability to become a guide as well when taking tourists to their destination. This contributes to additional income for workers around tourist attractions. Apart from contributing to the surrounding community, Benang Stokel 
Desi Suryati, Baiq Salkiah, The Existence Of Benang Stokel Waterfall Tourism To Community Income.

Waterfall Tourism also contributes to the regional income of Central Lombok Regency from the tourism sector.

Keywords: Income; Society; Waterfall Tour.

\section{INTRODUCTION}

Tourism development programs carried out by the government and the private sector prioritize efforts to increase the number of tourist visits because they can generate significant sources of income. COVID-19, which began to spread in Indonesia at the end of March, paralyzed all aspects of life and did not work normally. Production and consumption activities began to be hampered and even the closure of production activities and tourist attractions in various regions and regions. The sector that has been greatly affected is the tourism sector. One of them is in Central Lombok Regency. Even though there was continuous paralysis, it did not last long because in early September tourist attractions began to open again even though they followed standard health protocols.

The number of tourists began to arrive, the increase in the number of tourist visits to tourist attractions and directly affected the economy of the surrounding communities. In the efforts of the sector to develop tourism, along with its development it will regulate various impacts both directly and indirectly from economic factors and outside of the economic activity. The impacts are in the form of positive impacts and negative impacts on the general public and the people around the tourist attractions. Development in general on improving and enhancing people's welfare. However, even the efforts to implement this development cannot be separated from the impacts it creates, either directly or indirectly, on the surrounding environment, either in a short or a short period of time or in a long period of time.

There are so many natural resources that support the development of tourist attractions, even in various regions in Indonesia. The ability to manage natural resources will have an impact on the ability to generate income, both for family, national and international income. One of them is a tourist spot. The definition of tourism based on a regional perspective (Government of West Nusa Tenggara, 2013) is a travel activity carried out by certain individuals, groups, groups of people by visiting certain places of interest for picnic purposes, personal development, or to see other sides of a tourist attraction visited temporary. With a tourist destination, it is referred to as a tourism destination, which is a geographic area contained in one or many areas in which there are tourist attractions, public 


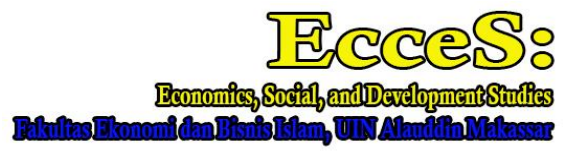

Volume 7 Number 2 Ed. December 2020 page: 177-197 p-ISSN: 2407-6635 e-ISSN : 2580-5570

facilities, accessibility, and communities that are interrelated and complement the realization of tourism

The tourism sector is a leading sector that has the potential to be further developed, especially in West Nusa Tenggara. The potential as a superior provides opportunities for the tourism sector to continue to be developed so that it contributes greatly to economic development, especially for the income of the people around tourist attractions. Tourism is an activity that has a domino effect from a series of tourism activities carried out. The tourism development process is directed towards increasing tourism into a mainstay sector capable of making activities not only oriented to the economic aspect but other related sector activities, to improve the welfare of the community.

The function of tourism, in general, includes three aspects, namely economic aspects (in the form of taxes and sources of foreign exchange), social aspects (creating job opportunities), and cultural aspects (showing various cultures to visitors as tourists). This existing aspect applies not only to visitors from outside but also to visitors from their own regions who are increasingly contributing to their role in taking part in the tourism sector (Islamy, 2019). The results showed that the income in the tourism sector made a positive contribution to economic growth so that the focus of economic policy was more focused on tourism promotion because it could be a potential source of income (Ekanayake and Long, 2012).

The growth of the tourism sector has an impact on economic growth in several aspects. First, the tourism sector becomes a source of foreign exchange to obtain raw materials for the production process. Second, tourism development provides capital stimulus in the infrastructure sector. Third, the development of the tourism sector provides a direct, indirect, and induced stimulus to the development of other economic sectors. Fourth, tourism contributes to job creation and increased income. Fifth, tourism fosters positive economies of scale. Tourism is also an important factor in the dissemination of technical knowledge, encouraging research and development, and the accumulation of human capital (Azhar, 2020).

The results show that there is a positive relationship between the existence of tourism and national income (GRDP) which impacts long-term personal income. On the other hand, the role of the tourism sector greatly supports the large contribution of capital, both domestic and foreign capital. Therefore, it must be developed by applying dynamic 
Desi Suryati, Baiq Salkiah, The Existence Of Benang Stokel Waterfall Tourism To Community Income.

policies in promoting the tourism sector. Promotion leads to business opportunities, job opportunities, and poverty alleviation. (Tabash, 2017)

West Nusa Tenggara has considerable tourism potential with all the advantages of each destination. The existing potentials are one of the government's concerns to be developed with a strategic planning pattern and rooted in the conditions of wisdom possessed by local communities. The existing tourism potentials are starting to be addressed and designed based on the tourism potentials they have. So far, the tourism programs implemented have been quite successful, it is proven that there are 99 villages in NTB that have been designated as NTB tourist destinations (Pemda NTB, 2019).

One of the well-known tourist areas in NTB is tourism on the island of Lombok. Almost all districts in Lombok provide various types of tourism and Central Lombok is a tourist area that offers many types of tourism, ranging from beach tours, waterfall tours, cultural heritage tours, and forest tourism. (Suryani et al., 2020). An enchanting natural tourist destination for both foreign and local tourists in Central Lombok Regency is the Benang Stokel Waterfall Tour in Aik Berik Village, North Batukliang District. In recent times, this tourist destination has become the focus of development by both the village, district, and provincial governments. The existence of Benang Stokel Waterfall Tourism is able to give birth to various other business sectors such as tour guides, homestays, MSMEs, transportation services, parking services, and others. Of course, these business sectors absorb labor and automatically have a significant impact on people's income levels. The purpose of people doing tourism depends on frequent visitors, visits to tourist attractions are a concern for the local government to be developed so that they become a potential sector that produces an image that attracts other people to visit tourist attractions. In addition, the benefits of using resources are maximized (Baker, 2019).

Based on the characteristics of the people in Central Lombok Regency, especially those around the waterfall, which work as a farmer with an average level of education at the secondary school level and below. Business opportunities that are getting narrower have resulted in the community around the tourist attractions having to try their best in meeting the needs of family life. Several studies related to tourism villages in Lombok have previously been conducted. However, information about tourist villages in Central Lombok is still limited, even though the potential tourist attraction in the form of nature, culture, and community creativity in the form of very interesting products. The results of previous research show that most of the tourist attractions on the island of Lombok are minimal with supporting accommodation. The development of the tourism sector has implications for all 


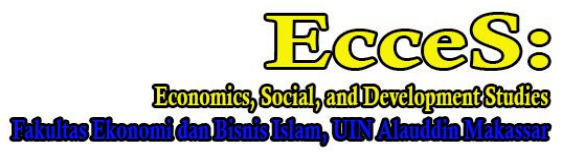

Volume 7 Number 2 Ed. December 2020 page: 177-197 p-ISSN: 2407-6635 e-ISSN : 2580-5570

existing sectors. Unique tourist attractions are a determining factor for tourists' motivation to travel, as well as an important reason to consider why a tourist chooses a destination. Tourist attractions are also an aspect that determines tourist satisfaction and comfort which will have an economic impact on the community on the sustainability of tourist destinations (Azhar, 2020).

The management of stochastic waterfall tourism has a positive effect on the welfare of the community. Therefore, this waterfall tour has a huge impact on the economy of the community. In addition, the reopening of this tourist spot even though it is still in a state of the COVID-19 pandemic has an effect on people's income. Residents who do not have a job have the greatest opportunity to do business again or take advantage of the opportunities that exist around waterfall tourism. Many things can be done with the existence of a tourist attraction because it can attract the attention of many people. Not only attracting the attention of domestic tourists and even foreign tourists who are also interested in visiting. The prolonged COVID-19 pandemic has resulted in economic paralysis because many employees and workers are being sent home. This is a burden on the family, especially in meeting their daily needs. Community income. which is limited is becoming less and less even completely absent during the Covid pandemic.

The income of the people around the Benang Stokel Waterfall Tour is generally very limited. The production capacity of the community is also limited because most of the people work in the agricultural sector. The existence of nature which is still natural makes people have to adjust to the surrounding environment. The tourism potential that is located around is an opportunity for the surrounding community to carry out economic activities. The existence of Benang Stokel Waterfall Tourism which is quite influential for the welfare of the community has certainly attracted the attention of various groups. This economic potential and employment of labor is certainly a special attraction for tourism actors or businessmen. Of course, this interest does not only come from the residents of Aik Berik Village but also from other villages. Based on the above conditions, the community needs to be optimized for human resources so that their role can be maximized in tourism activities in their area in order to increase income.

The value of use and benefits from the existence of Stokel waterfall tourism in the community must be obtained maximally because in any situation tourism-related activities will always require interaction and adaptation with the people around them. The interaction 
Desi Suryati, Baiq Salkiah, The Existence Of Benang Stokel Waterfall Tourism To Community Income.

that is built will bring up various kinds of activities that have economic value and selling value. Referring to the results of previous research, Saktiawan in Dharmawan et al., (2014) revealed that the most important thing for developing a tourism village is to involve the village community in every aspect of tourism in the village. The community participates directly in tourism activities in the form of providing services which result in increasing community income outside of their daily economic activities. Dharmawan et al., (2014) therefore activities for tourism in the Benang Stokel Waterfall Tourism area should be followed by additional income, and the community around the tourist location can live materially in prosperity. On the basis of the above background, a study was carried out on the existence of stochastic waterfall tourism on people's income in Central Lombok Regency.

\section{THEORETICAL REVIEW}

Tourism is an activity that is carried out in the short term by including various kinds of tourism components to visit a tourist spot with the aim of getting pleasure and not for earning income. Meanwhile, tourism is a conscious activity carried out by humans to get services alternately between everyone in a country for a temporary period of time to find various kinds of satisfaction and different from what they experience where they get a permanent job (Aulia, 2019). To get that satisfaction, it must be balanced with a variety of services and facilities according to your needs.

The definition of tourism is a variety of tourist activities balanced with various facilities and services provided by the community, businessmen, government, and local governments. Tourism is an activity that is fun (leisure) which is characterized by spending money or engaging in consumptive activities. Middleton in Irawati et al., (2019) provides a deeper definition of tourism products, namely "The tourist products to be considered as an amalgam of three main components of attraction, facilities at the destination and accessibility of the destination". This means that tourism products are generally formed from three main components, namely tourist attractions, facilities in tourist destination areas, and accessibility.

Tourism activities require a variety of resources, both natural and human resources. Labor is one of the income source instruments in production activity. Human resources in other words production activities are labor. The labor-related theory presented by Adam Smith explains that labor productivity can be increased based on specialization, meaning that work is done based on individual choices that are tailored to their respective talents and 


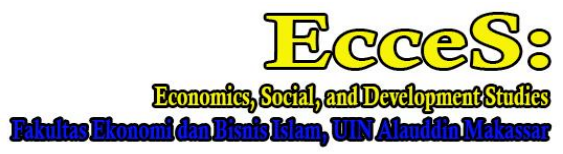

Volume 7 Number 2 Ed. December 2020 page: 177-197 p-ISSN: 2407-6635 e-ISSN : 2580-5570

expertise so that they can carry out a professional division of work. The increasing number of tourist visitors will increase the number of jobs for the surrounding communities. The effectiveness of the time used in work to provide free time to do the job. The effectiveness of the division of labor at the increased level of production will result in society becoming an innovative, creative, and productive society (Hastarini, 2017).

Supported by the theory presented by Alfred Marshal which reveals that there is a derivative demand for labor needs. If there are production activities, the demand for labor will also occur. This means that the increase in the number of workers working is influenced by the large number of production activities carried out. Therefore, in economic activity, a large amount of capital is needed to maintain the business being carried out as well as the existence of tourism in the tourism sector. According to the Neo-Classical theory, the ratio between capital and labor can change better. The combination of the amount of capital and the amount of labor required changes based on the quantity of production expected. The amount of capital owned has an influence on the amount of labor used (Bawuno et al., 2015).

Based on the law of labor demand, it states that the demand for labor is a result of the low wages or salaries of workers that are given. If the requested salary is high, the producer looks for other workers whose salary is lower than the first. This is caused by various factors, including the high number of labor force entering the labor market and the wages and skills possessed by these workers (Wicaksono, 2002).

But on the other hand, Keynes has a different view from classical and neo-classical theory, namely that the specialization stated in classical theory applies to a uniform or homogeneous workforce of both elements while in reality, the labor is not uniform or homogeneous. Domestic labor mobility is not as free as classical assumptions because there are still family ties and uncertainty about the types of work in new places. The difference between Keynes's view and classical theory is also from the assumption that the demand and supply of labor are always balanced (equilibrium) because prices are flexible, so according to Keynes the labor market is not balanced, because wages are never flexible, demand and supply are almost never balanced resulting in frequent unemployment. Based on the labor market theory, the labor market follows the equation of the supply of goods, namely if the output (Q) increases, the number of people who get jobs or the level of employment $(\mathrm{N})$ also increases. Conversely, the number of people who will find work falls 
Desi Suryati, Baiq Salkiah, The Existence Of Benang Stokel Waterfall Tourism To Community Income.

when productivity falls. The emphasis of Keynes's theory is more on the macro / large process, namely towards general equilibrium (Pujiati, 2011).

In a Neoclassical economy that the supply or supply of labor will increase when the wage increases. Conversely, the demand for labor will decrease if the wage level increases, so the neoclassical theory assumes that the quantity of labor supply equals demand. The condition when the supply of labor is always the same as the demand is called the equilibrium point (point E). in terms of supply and demand, there is no unemployment. In reality, the equilibrium point has never been reached because the information is never perfect and institutional barriers always exist (Chusna, 2013)

The different views of the concept of labor in neoclassical and Keynesian thinking can be seen from the theory of neoclassical growth and the short-term theory of Keynes. The neoclassical theory explains that in the long run, fixed capital goals will occur full employment meaning that in the long run, the aggregate supply curve is perfectly inelastic, this results in unemployment or excess supply of labor in the Neolacic framework, difficulties in getting a job are only temporary in the long run will end up with itself through the price mechanism, namely the real wage level. While different from Keynes's view, in the short run the overall supply curve will be perfectly elastic due to the unchanged wage rate. The implication of this theory is that unemployment is not temporary but will always occur if it is not regulated in the market mechanism to get a balance so that it requires government intervention.

In addition to the level of labor productivity based on the opportunities that can be obtained in the tourism sector, one of the efforts to maintain the existence of tourist attractions is by paying attention to amenities. Adequate facilities so as to provide easy access for tourists are things that must be considered properly. Amenities are facilities that support a tourist activity, both tourist attractions and tourist villages that are needed by tourists. The results of previous research showed that the average amenity value of the Central Lombok tourist village was 2.60 in the category of less supportive of tourism development. This means that the amenities in Central Lombok Regency are generally still low in value (Azhar, 2020).

The high and low value of the amenities reflects the carrying capacity that can be used as a benchmark that in the right tourism there is easy access for tourists to visit. The intensity of the arrival of tourists who visit gives a positive value to the amount of income that can be obtained by the community around the tourist spot. This is supported by the results of previous research which states that a tourist attraction (ODTW) is a form and 


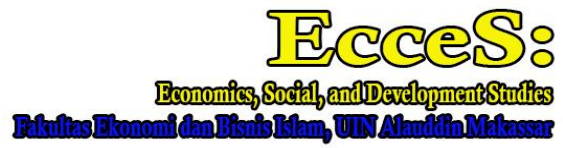

Volume 7 Number 2 Ed. December 2020 page: 177-197 p-ISSN: 2407-6635 e-ISSN : 2580-5570

facility that has a relationship and becomes the reason or cause for tourists to visit a certain area or place. Objects of tourist attraction can be divided into 3 (three) namely: natural or environmental tourism objects or called ecotourism, socio-cultural tourism objects, and special interest tourism objects (Khotimah and Wilopo, 2017). The object of this attraction is a magnet that is created to attract the attention of visitors so that the arrival of busy visitors contributes a lot to the income of the surrounding community.

Emphasis on the existence of tourist attractions is able to contribute to community income. Innovation and creativity in generating income are reflected in its ability to create new jobs tailored to the needs of visiting tourists. A creative economy is the ability to create something with innovative value that has a high selling value both in producing goods and services. The potential of tourism is used as one of the mainstay sectors of the economy that is able to contribute to influencing other economic sectors, such as providing jobs, increasing people's income, and earning foreign exchange. Because any changes that occur in the base sector will have a multiplier effect in the regional economy (Islamy, 2019).

\section{METHODS}

This study uses descriptive research methods, namely research methods that aim to provide a systematic, factual, and precise description of the facts and characteristics of a particular population or area. The approach used is a quantitative approach, namely an approach in which there is a process, submission of temporary answers, field observations, analyzing data, and concluding data to a compilation of writing using aspects of size, calculation, and formulation by ensuring it is in numerical data. Determination of the sample based on purposive sampling (purposive sampling) is a non-random sampling technique in which the determination of sampling is by determining specific characteristics that are in accordance with the research objectives so that it is expected to be able to answer the research problem. Purposive Sampling is a study in which the sample is a purposive sample based on predetermined criteria (Suryati \& Rohmiati, 2020).

Research in Benang Stokel Waterfall Tourism was used as an option for the location studied based on the reason that the research location has certain characteristics, one of which is the ownership of water discharge from springs so that the water flows throughout 
Desi Suryati, Baiq Salkiah, The Existence Of Benang Stokel Waterfall Tourism To Community Income.

the year which results in being different from other waterfall tours. Besides that, the tourist spot of the Benang Stokel waterfall is a natural tourist spot with more visitors than other tourist attractions in Central Lombok Regency. The tourist spot of Benang Stokel Waterfall has natural potential in the form of a waterfall that is above the altitude with a natural panorama that attracts attention and soothes the eye. Benang Stokel Waterfall Tour is one of the natural tourist destinations that attract tourists to go on an adventure in the open air.

Data sources are primary data taken from filling out respondents' questionnaires directly related to income and the existence of Benang Stokel Waterfall Tourism, equipped with secondary data from local government and related agencies as a complement to data obtained from previous primary data. There are 2 variables in this research, namely the tourism variable of Benang Stokel Waterfall and the variable of income. The dependent variable is a variable that is affected by other variables and the independent variable is a variable that is not affected or dependent on other variables. The data collection method used an instrument in the form of a closed questionnaire using a Likert scale. A closed questionnaire is a list of questions along with the five answer options given to respondents to fill in. Observation, the activity of observing what is happening around the Benang Stokel Waterfall Tour and documentation, documenting both in the form of data and images to complement the required data. Data analysis used statistical tests and statistical analysis using the SPSS program.

\section{RESULTS AND DISCUSSION}

The results showed that several characteristics of respondents were grouped based on gender characteristics, age characteristics, educational level characteristics, job characteristics, and income type characteristics. The grouping of these characteristics is adjusted to the results of the questionnaire distributed to the respondents so that the percentage of each characteristic of all respondents in the study can be known.

Based on gender characteristics, male respondents were $66.67 \%$, female respondents were $33.33 \%$. Respondents who are male sex dominate the work carried out in the area of Benang Stokel Waterfall Tourism than female respondents. Type of work such as tour managers, travel services, tour guides, and others. The natural conditions of Benang Stokel Waterfall Tourism are extreme, the road is very slippery, you have to be careful to pass it to reach the destination or the waterfall. It really requires physical strength to 


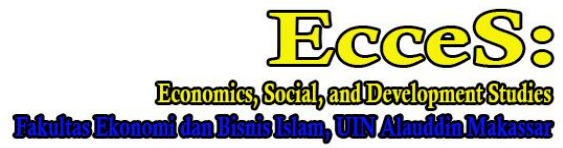

Volume 7 Number 2 Ed. December 2020 page: 177-197 p-ISSN: 2407-6635 e-ISSN : 2580-5570

achieve it. Meanwhile, more women are sellers who sell their wares in the area where the Benang Stokel Waterfall Tour is located.

Based on the characteristics of the age of the respondents, more of them are dominated by young people who still have maximum physical strength at work, both from employees, managers, and sellers who are around the Benang Stokel Waterfall Tour. Based on the age division, 3.3 percent of respondents aged 15-19 years. Those aged $20-30$ years were 50 percent and respondents aged 30 years was 46.7 percent. Economic dependents aged 30 years and over are reasons to be used as respondents. However, the more dominant respondents are 20-30 years old, this is because respondents who are 20-25 years old are respondents who are physically and mentally capable in accordance with the conditions of the Benang Stokel Waterfall Tour. So that they are able to rely on their physical strength to work around the Benang Stokel Waterfall Tour. It is also rare to find respondents of older age because the terrain requires traders to have maximum physical strength. This is also in accordance with the theory stated that workers are a group of people at the working age, where they are able to work or carry out economic activities to produce goods or services to meet their needs.

Based on the level of education, 30 percent of respondents with junior high school education were not continuing their education because of low economic factors. They only reached the status of junior high school education without completing school completely, so that with the Benang Stokel Waterfall Tour they had no more reason not to do work. And can help family finances to be better. 50 percent of respondents who graduated from high school, the reason for not continuing their education was because there was no motivating factor from their parents to continue their education. With the Benang Stokel Waterfall Tour, they have the opportunity to work around the Benang Stokel Waterfall Tour in Aik Berik Village. Reluctance to continue studying is caused other than by factors from the family as well as factors from oneself.

Meanwhile, 20 percent of respondents completed their undergraduate degree. They are a small part of the majority of the existing respondents. They still have a more advanced mindset compared to other respondents. In addition, because there is a request from the manager of the tourist spot to work and be positioned in administration. Based on the characteristics of this level of education, the last education of the respondents was mostly in high school education. The tendency to work around tourist attractions is very dominant for 
Desi Suryati, Baiq Salkiah, The Existence Of Benang Stokel Waterfall Tourism To Community Income.

them, apart from the desire to continue their education to tertiary education, which is still low, which is caused by background and factors of unsupportive economic limitations.

The characteristics based on the respondent's occupation based on the occupation of tourism employees or employees were 66.67 percent. Tour employees such as tour managers, administrative staff, parking attendants, motorcycle taxi drivers, ticket managers, tour guides, guides, security officers at the Benang Stokel Waterfall Tour. Respondents as traders such as rice pack traders, pop ice traders, fruit traders, coffee traders, pop noodle traders, fresh vegetable traders, cilok traders, and drinking water traders were 30 percent. While students or student respondents who work around tourist attractions amounted to 3.33 percent. They work to help reduce the burden on parents or increase tuition fees.

Based on the results of previous research, the existing tourist attractions can absorb a large number of workers and even contribute to reducing the number of unemployed. The absorption of labor has occurred in several micro sectors such as the increasing number of hawkers, food and soft drink shops, local guides, motorcycle taxi drivers, and parking attendants (Punarbawa, 2016)

The existence of tourism can have an impact on the economy which leads to the income of the surrounding community. The positive impact it causes is an increase in community income, namely the existence of waterfall tourism, which makes the economic activities of residents around tourist attractions become crowded. work occurs as a result of starting to build a more varied work polarization according to the needs of tourists visiting tourist attractions. Making souvenirs that can be used as provisions for returning home for tourists, increasing village government income through a taxation mechanism that is shared with the manager of tourist attractions, increasing demand for local products such as fruit or food as a characteristic that is used as a tourist icon for tourist visitors, improving facilities for the community such as supporting facilities, comfortable bathrooms, motorcycle taxi drivers who are ready to help deliver anywhere and spur the development of locations or land to be more productive, starting with the idea of developing dead land around tourist attractions to be more productive and productive (Febriana and Pangestuti, 2018).

Based on the income characteristics of the respondents, respondents who work as parking attendants, ticket attendants and traders around the Benang Stokel Waterfall Tour earn an income of Rp. 100,000 - Rp. 600,000 per month is 90 percent. Before COVID-19, their income could reach Rp. 500,000 - Rp. 1,000,000 per month. However, due to the covid outbreak, their income has decreased by up to 50 percent. Respondents who earn 500,000 $1,500,000$ are 10 percent. These respondents are managers of tourist attractions or 


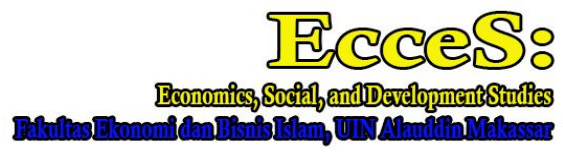

Volume 7 Number 2 Ed. December 2020 page: 177-197 p-ISSN: 2407-6635 e-ISSN : 2580-5570

employees at the tourist spot of Stokel thread. Their income fluctuations also have an impact on the existence of COVID-19, which initially reached Rp. 2,000,000 per month before the COVID-19 pandemic.

The reopening of tourist areas during the Covid pandemic was still applying health protocols. The greater level of dependence of the surrounding community with the reopening of the Benang Stokel Waterfall Tourism area is an advantage in order to increase income in the family. The lack of community income in the agricultural sector as the main source of income motivates them to earn income at the Benang Stokel Waterfall Tour.

In line with the results of previous research. The results show that tourism activities can create new business opportunities and job opportunities for people around tourist attractions. Employment and business opportunities that can be developed are very many for use by indigenous people in increasing income. Utilizers of tourism business and work opportunities tend to make tourism business and work their sole livelihood, including making business opportunities and job opportunities in the tourism sector a main job with side jobs in other sectors (Ni Putu Deni Rena Ati, 2018). Although there are still some people whose income in the tourism sector is classified as uncertain, so that employers and workers still rely on income from their main job to meet household needs. This is because their main job is to have a steady income every month.

The development of tourism is actually directed so that tourism activities become one of the basic/mainstay sectors of the economy capable of driving other economic sectors in order to provide jobs, increase people's income, and earn foreign exchange. The tourism sector is a potential sector. This can be seen from its maximum contribution so as to increase the rate of the economy. The fast growth rate every year is the contribution of several leading sectors, such as in terms of transportation, transportation business fields, and services. Other important categories are Provision of Accommodation and Food and Drink Construction, and Trade has the potential to be maximized more to be increased in accelerating the rate of economic growth. The results showed that there is a new economic force found in tourism, namely the creative economy. The creative economy is a new idea in the economic system that places human information and innovation as part of the main production factors (Islamy, 2019).

The significance value of variable $X$ is 0.268 greater than 0.05 , which means that the data for variable $X$ is normally distributed. And the significance value of the variable $Y$ is 
Desi Suryati, Baiq Salkiah, The Existence Of Benang Stokel Waterfall Tourism To Community Income.

0.030 which is greater than 0.05 , which means that the $Y$ variable is normally distributed. This means that Benang Stokel Waterfall Tourism data and income data met the requirements to be continued at the next testing stage. The underlying assumption in the analysis of variance (ANOVA) is that the variants of the population are the same. As a test criterion, if the significance value is $>0.05$, it can be said that the variants of two or more data groups are the same. The Levene test has the main objective of knowing the differences between the two groups of data with different variants. The calculation results of this test will show the significant value of two different data groups. The significance value of 0.069 is greater than 0.05 , which means that the variance of waterfall tourism data and income is homogeneous. This means that the Benang Stokel Waterfall Tourism data and income data meet the requirements to be continued at the next statistical testing stage.

The test results show that a tolerance value of 1,000 is greater than 0.10 and a VIF value of 1,000 is less than 10 , so it can be concluded that there is no multicollinearity. This means that the Benang Stokel Waterfall Tourism data and the income data did not have multicollinearity so that they met the requirements for continuing testing at a later stage. Subsequent statistical tests were carried out using the SPSS program to see the magnitude of the influence of the presence of Benang Stokel Waterfall Tour on community income in Central Lombok Regency.

Statistical Test Table

The existence of Benang Stokel Waterfall Tourism with an income level

\section{Coefficients}

\begin{tabular}{|c|c|c|c|c|c|c|}
\hline & \multirow[t]{2}{*}{ Model } & \multicolumn{2}{|c|}{$\begin{array}{c}\text { Unstandardized } \\
\text { Coefficients }\end{array}$} & \multirow{2}{*}{$\begin{array}{c}\text { Standardized } \\
\text { Coefficients } \\
\text { Beta }\end{array}$} & \multirow[t]{2}{*}{$\mathrm{T}$} & \multirow[t]{2}{*}{ Sig. } \\
\hline & & $B$ & Std. Error & & & \\
\hline 1 & $\begin{array}{c}\text { (Constant) } \\
\text { cX }\end{array}$ & $\begin{array}{c}45.357 \\
243\end{array}$ & $\begin{array}{c}6.960 \\
114\end{array}$ & 373 & $\begin{array}{l}6.517 \\
2.127\end{array}$ & $\begin{array}{l}.000 \\
.042\end{array}$ \\
\hline
\end{tabular}

Source: Primary Data Processed in 2020

The table above shows that the statistical test for the $t$ value of 2.217 is greater than the $t$ table value of 2.045 at a significant level of $5 \%$ or $2.217>2.045$. it means that the hypothesis of the existence of Benang Stokel Waterfall Tourism has an effect on people's income in Central Lombok is proven. Meanwhile, the significance value obtained is 0.042 $<0.05$, meaning that waterfall tourism has a significant effect on people's income in Central Lombok Regency. 


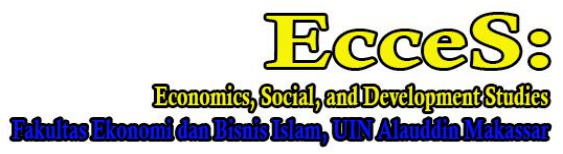

Volume 7 Number 2 Ed. December 2020 page: 177-197 p-ISSN: 2407-6635 e-ISSN : 2580-5570

The results of the above research are supported by the results of previous research conducted by (Kim et al., 2006) showing a causal relationship between tourism development and economic development. The causality test with the cointegration approach shows the direction of economic growth and tourism development, meaning that the two factors are mutually correlated and mutually reinforcing. So that the development of the tourism sector has an influence and impact on people's income which will have an impact on overall economic growth.

The existence of this waterfall has an impact on the income of the surrounding community. The positive impact it causes is an increase in community income, namely the existence of waterfall tourism, which makes the economic activities of residents around tourist attractions become crowded. work occurs as a result of starting to build a more varied work polarization according to the needs of tourists visiting tourist attractions. People who initially did not have a job were able to find work with the Benang Stokel Waterfall Tour. This is in line with the results of previous research (Febriana and Pangestuti, 2018) which states that the impact of tourism is an increase in community income, maximum absorption of labor, additional revenue for local governments such as entrance taxes, local products are starting to be seen as by tourists, the addition of facilities for the community in accelerating the development of the location or land becomes more fully functional (productive).

The existence of Benang Stokel Waterfall Tourism provides a business opportunity for people around tourist attractions so that it contributes to community income. Some work opportunities are carried out at tourist attractions and around the Benang Stokel Waterfall Tour such as local guides, street vendors, security guards, parking attendants, and others. Apart from contributing to the surrounding community, Benang Stokel Waterfall Tourism also contributes to the regional income of Central Lombok Regency from the tourism sector. With the Benang Stokel Waterfall Tour in Central Lombok Regency, it creates many opportunities for the community, especially the opportunity to get a job outside the agricultural sector. The more crowded tourists who visit are able to open wider job opportunities and also increase opportunities to increase income.

Supporting and supporting facilities and infrastructure at tourist attractions, both in the form of goods and services and services available around tourist attractions, have a huge effect on the capacity of the number of visitors at tourist attractions. The availability of 
Desi Suryati, Baiq Salkiah, The Existence Of Benang Stokel Waterfall Tourism To Community Income.

this facility is one form of maximum service in attracting the number of tourists visiting. With the many facilities available, new types of work will also be available, thus opening up opportunities for the surrounding community to carry out various economic activities. When economic activities and activities increase, it will automatically increase people's income or income. This is supported by previous research which states that tourism development in Lombok has begun to show changes with the availability of various kinds of facilities and has a positive impact on employment and community income (Jalaludin, 2019).

Similar to what was conveyed in the results of previous research, the results of the study stated that an increase in direct investment in the tourism sector could increase economic growth in the tourism sector such as direct foreign tourist arrivals to tourist destinations coupled with direct tourism promotion to the international market. Because tourism promotion is an easy and effective tool to attract more tourists so that it benefits the country from the side of Foreign Direct Investment (FDI). This has contributed significantly to national economic growth. (Ly-Pham ThiMinh, 2017)

Other findings indicate that the existence of the Benang Stokel Waterfall Tour has resulted in a shift in livelihoods and employment opportunities for local residents from the agricultural sector to the service sector, such as transportation services and tour guides, the development of the trade sector and home industries such as shops, food stalls. , beverage stalls, hawkers, and street vendors. In addition, the income earned has not been able to fully compete with the selling power offered by residents around tourist attractions because they are still unable to compete with investors, especially traders, who are more likely to increase the price of merchandise to increase their income, but this actually makes tourists shop outside tourist attractions. because the price is cheaper so that people's income cannot continue to increase. In accordance with the sound of the demand theory which states that the price determines the high or low demand for goods. Demand for goods decreases when the price of an item increases and demand for goods will increase if it is followed by a decrease in the price of the goods, which means that the tendency is that consumers prefer to seek cheaper prices.

Benang Stokel Waterfall Tour is a destination that has its own uniqueness in attracting visitors. The authenticity of the natural panorama gives a nuance of beauty that is refreshing and pleasing to the eye so that it becomes comfortable for long in this tourist area. This is the main supporting factor for the existence of this tourism. In addition, the existence of this tourist destination fosters a spirit of adventure in visitors to more freely explore the sources of beauty that exist in tourist attractions. With this natural beauty, 


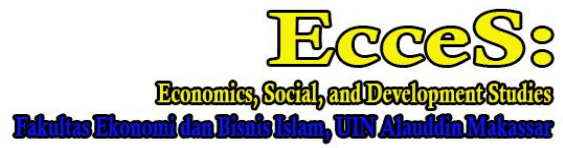

Volume 7 Number 2 Ed. December 2020 page: 177-197 p-ISSN: 2407-6635 e-ISSN : 2580-5570

visitors will be crowded, thereby increasing economic activity around tourist attractions. The high level of economic activity has an impact on the income of the people around the Benang Stokel Waterfall Tourism area so that whatever form of economic activity is carried out it must have an effect on the income of the people around tourist attractions and the people of Central Lombok in general.

The opening of business opportunities so that the absorption of labor at the tourist site of the Tilapia waterfall is part of the changes that occur, but there are differences in views with the results of research (Suwiryanta, 2003) which states that the existence of tourist attractions that open new jobs and develop productive land in support The tourism sector in the tourist area will actually result in many hawkers disrupting tourist visits. The hawkers are mostly done by school-age children and underage children. The increasing number of hawkers makes tourists feel disturbed because sometimes there is an element of coercion in the sales system. This reduces the attractiveness of visiting tourists so that the intensity of tourist visits decreases and affects the income earned by the community.

Meanwhile, the transition of economic activities carried out by the surrounding community from the agricultural sector to the trade sector has shifted the livelihood structure of the people around tourist attractions. These changes have an impact on the socio-economic aspects of society and other aspects of life. The effect of this is revealed in research (Febriana \& Pangestuti, 2018) that in addition to positive impacts there are also negative impacts on the tourism sector, namely the incidence of other costs in the local economy, meaning that the income received by the local community is reduced because it is charged for other costs such as residual disposal of waste generated by tourists visiting tourist attractions. The costs that must be incurred in this case are the costs of transporting the waste or residual waste and costs for environmental improvement or AMDAL and the second negative impact is the unequal distribution of income which means that there is a GAP or distance between the rich and the poor so that the poor get poorer and the rich get richer. Socially, this GAP will create a gap between one community and another. This gap has an impact on the social life of the community around tourist attractions

The same thing was conveyed by Suwiryanta (2003) who stated that the existence of tourism that creates new jobs and the development of productive land in supporting the tourism sector around tourist attractions will actually result in the mushrooming of hawkers which are usually carried out by underage children, the number of hawkers makes tourists 
Desi Suryati, Baiq Salkiah, The Existence Of Benang Stokel Waterfall Tourism To Community Income.

feel disturbed because usually in sales there is an element of coercion, the shift of labor from the agricultural sector to the trade sector. The polarization of changes that occurs has an impact on economic life and other social life

Followed by research results from Febriana and Pangestuti (2018) that in addition to positive impacts there are also negative impacts on the tourism sector, namely the incidence of other costs in the local economy, meaning that the income received by the local community is reduced because they are charged for other costs such as the remaining waste disposal generated. by visitors or tourists to tourist attractions. Expenditures are used to finance the transportation of waste or residual waste and costs for environmental improvement or AMDAL and the second negative impact is the unequal distribution of income which means there is a GAP or the distance between the rich and the poor so that the poor get worse in poverty and the rich increasingly reaping large profits. Socially built GAP will cause a gap between one society and another. This gap has an impact on the social life of the community around tourist attractions.

Another factor that causes obstruction of the existence of the Benang Stokel Waterfall Tourism is because the route to the tourist location is very dangerous and challenging so that it hinders the journey to the tourist location. Meanwhile, visitors will feel at home doing recreational activities to tourist attractions if supported by adequate facilities and infrastructure around the tourist sites. However, it cannot run by itself because activities in each sector must involve the government, as happened in the tourism sector. This is in line with Keynes's theory which states that in every economic activity there needs to be government intervention and intervention so that economic activities in any sector can run well.

\section{CONCLUSION}

The existence of the Benang Stokel Waterfall Tour has a significant influence on the income of the community, especially Central Lombok. The influence of the existence of Stokel waterfall tourism provides business opportunities outside the agricultural sector for the surrounding community so that it contributes to community income. Business opportunities shift people's livelihoods so that they shift more to the service sector. Even motorcycle taxi drivers, traders, and motorcycle taxis, or parking attendants who are around tourist attractions have a mindset guide. The existence of Benang Stokel Waterfall Tourism can be maintained through facilities and services according to the needs of tourists in order 
Volume 7 Number 2 Ed. December 2020 page: 177-197 p-ISSN: 2407-6635 e-ISSN : 2580-5570

to provide opportunities and contribute to the income of the wider community, locally, nationally, and internationally.

\section{REFERENCES}

Aulia Basundhari W, Istijabatul Aliyah, R. S. 2019. Analiisi Permintaan dan Penawaran Wisata Kraton Kasunan Surakarta. Cakra Wisata, Volume 20.

Azhar Amir, T. D. S. \& F. R. 2020. Identifikasi Potensi Dan Status Pengembangan Desa Wisata Di Kabupaten Lombok Tengah, Nusa Tenggara Barat. Journal of Regional and Rural Development Planning (Jurnal Perencanaan Pembangunan Wilayah Dan Perdesaan), 4(2), 84-98.

Baker, D. M. 2019. Characteristic and Intentions of Cruise Passengers ti Return to the Caribbean For Land-based Vacations. 26.

Bawuno, E. E., Kalangi, J. B., \& Sumual, J. I. 2015. Pengaruh Investasi Pemerintah dan Tenaga Kerja Terhadap Pertumbuhan Ekonomi di Kota Manado. Jurnal Berkala IImiah Efisiensi, 15(04), 245-254.

Chusna, A. 2013. Pengaruh Laju Pertumbuhan Sektor Industri, Investasi, Dan Upah Terhadap Penyerapan Tenaga Kerja Sektor Industri Di Provinsi Jawa Tengah Tahun 1980-2011. Economics Development Analysis Journal, 2(3), 14-23.

Dharmawan, I. M. A., Sarjana, I. M., \& Yuhadhari, I. D. A. S. 2014. Strategi Pengembangan Desa Wisata Di Desa Belimbing Kacamatan Pupuan, Kabupaten Tabanan. E-Jurnal Agribisnis Dan Agrowisata, 3(1), 1-11.

Ekanayake, E., \& Long, A. 2012. Tourism Development and Economic Growth in Developing Countries. The International Journal of Business and Finance Research, 6(1), 61-63.

Febriana, Y. E., \& Pangestuti, E. 2018. Analisis Dampak Pengembangan Kepariwisataan dalam Menunjang Keberlanjutan Ekonomi dan Sosial Budaya Lokal Masyarakat. Jurnal Administrasi Bisnis (JAB), 61(4), 141-150.

Hastarini, D. A. 2017. Kajian Teori Pemikiran Ekonomi Mazhab Klasik dan Relevansinya pada Perekonomian Indonesia. Jurnal Ekonomi \& Bisnis, 2(2), 511-524.

Irawati, N., Utari, E. L., Listyalina, L., Tinggi, S., Ambarrukmo, P., \& Yogyakarta, U. R. 2019. Peningkatan Eksistensi Destinasi Wisata Watu Tekek Melalui Pengembangan Produk Wisata Berkelanjutan. Seminar Nasional UNRIYO [November], 18-28. 
Desi Suryati, Baiq Salkiah, The Existence Of Benang Stokel Waterfall Tourism To Community Income.

Islamy, N. 2019. Analisis Sektor Potensial, Dapatkah Pariwisata Menjadi Lokomotif Baru Ekonomi Nusa Tenggara Barat? Journal of Indonesian Tourism, Hospitality and Recreation, 2(1), 1-10.

Jalaludin, S. 2019. Dampak Pengembangan Pariwisata Dalam Meningkatkan Pendapatan Impact of Tourism Development in Increasing Community Income. 9(2), 197-203.

Khotimah, K., \& Wilopo, W. 2017. Strategi Pengembangan Destinasi Pariwisata Budaya (Studi Kasus pada Kawasan Situs Trowulan sebagai Pariwisata Budaya Unggulan di Kabupaten Mojokerto). Jurnal Administrasi Bisnis S1 Universitas Brawijaya, 42(1), 5665.

Kim, H. J., Chen, M. H., \& Jang, S. C. S. 2006. Tourism expansion and economic development: The case of Taiwan. Tourism Management, 27(5), 925-933.

Ly-Pham Thi Minh, Hieu-LeMinh, P.-T. T. 2017. The Relationship Between International Tourist Arrivals and Foreign Direct Investment: A Granger Causality Analysis. Acta Oeconomica Pragensia, 25(4), 3-12.

Ni Putu Deni Rena Ati, I Wayan Bagia, I. wayan S. 2018. Analisa Penuruna Pendapatan Sektor Pariwisata Sebuah Kajian dari Perspektif Manajemen Keuangan. Bisma: Jurnal Manajemen, 4(1), 17-23.

PEMDA.NTB. 2019. SK Gubernur tentang Penetapan Desa 99 Desa Wisata NTB. 2019.pdf.

Pemerintah Nusa Tenggara Barat. 2013. Peraturan Daerah Provinsi Nusa tenggara Barat No 7 tahun 2013 Tentang Rencana Induk Pembangunan Kepariwisataan Daearh Tahun 2013-2028. 36.

Pujiati, A. 2011. Menuju Pemikiran Ekonomi Ideal: Tinjauan Filosofis Dan Empiris. Fokus Ekonomi, 10(2), 114-125.

Punarbawa, M. A. 2016. Keterserapan Tenaga Kerja pada Industri Pariwisata di Kabupaten Buleleng tahun 2011-2015. Jurnal Program Studi Pendidikan Ekonomi, 6(2), 1-12.

Suryani, E., Furkan, L. M., \& Diswandi, D. 2020. Strategi Pengembangan Wisata Alam Hutan Irup Desa Saribaye, Kecamatan Lingsar, Lombok Barat. Jurnal PEPADU, 1(1), 64-73.

Suryati D \& Rohmiati Amini. 2020. Analisis Hasil Produksi Pertanian terhadap Kesejahteraan Rumah tangga Petani Muslim di Desa Anjani Kabupaten Lombok Timur. 14(6), 5-7.

Suwiryanta, A. 2003. Dampak Pengembangan Pariwisata Terhadap Kehidupan Sosial Budaya dan Ekonomi. Media Wisata Vol.2 No.1. 
Volume 7 Number 2 Ed. December 2020 page: 177-197 p-ISSN: 2407-6635 e-ISSN : 2580-5570

Tabash, M. I. 2017. The Role of Tourism Sector in Economic Growth: An Empirical Evidence From Palestine. International Journal of Economics and Financial Issues, 7(2), 103-108. Wicaksono, T. Y. 2002. Tingkat Upah, Inflasi dan Pengangguran: Aplikasi Model LucasRapping terhadap Pasar Tenaga Kerja Indonesia Tahun 1960-2001. In Jurnal Ekonomi dan Pembangunan Indonesia (Vol. 3, Issue 1, pp. 15-30). 